\title{
Rancang Bangun Sistem Informasi Akademik Madrasah Tsanawiyah Negeri 37 Jakarta
}

\author{
Liesnaningsih \\ Universitas Muhammadiyah Tangerang/Fakultas Teknik, \\ Program Studi Informatika \\ Jalan Perintis Kemedekaan 1/33 Cikokol Kota Tangerang TLP.55793251, 55772949, 55793802 \\ e-mail : liesnaningsih@gmail.com
}

\begin{abstract}
ABSTRAK
Sistem informasi akademik hingga saat ini pada umumnya merupakan sistem informasi offline, dimana informasi hanya dibuat secara manual baik melalui dokumen-dokumen resmi yang tersimpan, media cetak maupun lewat papan pengumuman yang terpasang di lingkungan sekolah. Berdasarkan uraian di atas, maka dilakukan peningkatan pelayanan dibidang informasi. Sistem informasi manual yang telah ada akan dikembangkan menjadi sistem informasi digital (terkomputerisasi) dalam bentuk sebuah website on-line. Website online ini dibuat dengan menggunakan script php dan database MySQL. Tujuan dari perencanaan sistem ini adalah memberikan kemudahan dalam penyampaian informasi pendidikan yang ada secara luas tidak hanya untuk para guru dan siswa tetapi juga dapat diakses oleh masyarakat umum melalui internet. Melalui pengembangan sistem ini akses informasi dapat dilakukan kapanpun dan dimanapun tanpa harus berhubungan secara langsung dengan sumber yang ada.
\end{abstract}

Kata Kunci: Sistem, Informasi, Akademik, Website

\begin{abstract}
Academic Information System up to now is off line information system generally, where information is only be created manually which are through official documents that are stored, print media and bulletin board on school's wall. Based on explanation above, then be increased services in the field of information. Manual information system become digital information system (computerize) in the form of online website. On this online website, it's used php script and mySQL database. The purpose of this planning system is facilitating in delivery of educational information widely, it's not only for the teachers and students but also accessible for public on internet. Through this development system, access information can be done whenever and wherever without directly related with existing resources.
\end{abstract}

Keywords: System, Information, Academic, Website

\section{PENDAHULUAN}

\section{Latar Belakang Masalah}

Teknologi informasi selalu mengalami kemajuan, sehingga menuntut instansi dan lembaga untuk menerapkannya dalam kegiatan sehari-hari. Lembaga pendidikan negeri maupun swasta memanfaatkan teknologi informasi sebagai penunjang operasional Kegiatan Belajar Mengajar (KBM), antara lain: penerimaan siswa baru, promosi, absensi, penilaian, atau kegiatan lain yang akan dilaksanakan sekolah.

Sistem informasi berbasis web memiliki kelebihan karena sistem informasi akademik berbasis web dapat diakses oleh siswa, guru, pegawai, dan stakeholder dimana dan 
kapanpun dengan menggunakan media internet.

Sekolah Madrasah Tsanawiyah Negeri (MTsN) 37 Jakarta merupakan lembaga Setelah melakukan pengamatan pada MTsN 37 Jakarta, penggunaanya dinilai masih kurang efektif dan efisien sehingga informasi mengenai penerimaan calon siswa, absensi siswa, jadwal pelajaran, jadwal Ujian Tengah Semester (UTS), jadwal Ujian Akhir Semester (UAS), pengumuman, nilai atau raport, data pribadi siswa, dan guru serta stakeholder (komite dan dinas) kurang dapat diterima secara cepat dan terbaru. Atas dasar pemikiran tersebut, penulis menyarankan kepada pihak sekolah untuk dibuatkan suatu aplikasi berbasis web dengan harapan kendala yang ada dapat diatasi.

\section{Maksud Penulisan}

Adapun maksud dari penulisan karya ilmiah ini antara lain:

1. Memberikan sumbangan pemikiran memecahkan atau mencari solusi sistem yang sudah ada dengan dibuatkan aplikasi berbasis web sehingga informasi tidak mengalami kesulitan.

2. Dengan hadirnya website ini, diharapkan dapat membantu siswa, guru, orang tua serta masyarakat untuk mendapatkan informasi aktual seputar pendidikan dan bentuk kegiatan yang ada di Madrasah Tsanawiyah Negeri (MTsN) 37 Jakarta.

\section{Metode Pengumpulan Data}

Metode pengumpulan data adalah serangkaian kegiatan atau cara untuk mendapatkan data atau informasi dari objek yang diteliti. Disini penulis menggunakan beberapa metode pengumpulan data diantaranya:

\section{Observasi}

Penulis melakukan pengamatan langsung terhadap kegiatan-kegiatan akademik yang berlangsung di MTsN 37 Jakarta yang berada di Jalan Kebon Dua Ratus RT.003/06 Kelurahan Kamal, Kecamatan Kalideres, Jakarta Barat.

2. Wawancara

Penulis melakukan tanya jawab kepada bapak Anwar Fikri, S.Ag selaku kepala madrasah, bapak Muhammad Effendi Agus, S.Ag selaku kepala tata usaha, lbu Afifah, S.Ag selaku kepala bagian pendidikan yang dalam proses pengolahan data kegiatan akademiknya sudah dilakukan dengan komputer menggunakan microsoft excel.

kurikulum, bapak Ibrachim, S.Pd selaku guru Teknologi Informasi Komunikasi (TIK), serta siswa di MTsN 37 Jakarta yang berada di Jalan Kebon Dua Ratus RT.003/06 Kelurahan Kamal, Kecamatan Kalideres, Jakarta Barat.

\section{Studi Pustaka}

Dengan metode studi pustaka ini penulis mendapat sumber data dari buku-buku dan jurnal yang berhubungan dengan studi literature pada buku atau referensi yang berkaitan dengan perancangan website.

\section{Ruang Lingkup}

Ruang lingkup masalah yang akan dibahas adalah perancangan program dalam bentuk website untuk pengolahan data dan informasi akademik pada Madrasah Tsanawiyah Negeri 37 Jakarta dimulai dari pengolahan data penerimaan siswa baru, pengolahan jadwal pelajaran siswa dan jadwal mengajar guru, absensi online, pengolahan nilai dan raport online yang dapat di akses oleh siswa di ruang siswa dan guru di ruang guru, serta menampilkan laporan.

\section{Landasan Teori}

1. Pengertian Rancang Bangun atau Perancangan

Susanto (2004:332) menjelaskan bahwa: Perancangan adalah spesifikasi umum dan terinci dari pemecahan masalah berbasis komputer yang telah dipilih selama tahap analisis.

2. Pengertian Sistem Jerry FiztGerald, Ardra F FiztGerald dan Warren D. Stallings dalam Jogiyanto (2005:1) Sistem adalah suatu jaringan kerja dari prosedur-prosedur yang saling berhubungan, berkumpul bersama-sama untuk melakukan suatu kegiatan atau untuk menyelesaikan suatu sasaran tertentu.

3. Pengertian Informasi

Menurut Davis (2003:28) Informasi adalah Data yang telah diolah menjadi sebuah bentuk yang berarti bagi penerimanya dan 
bermamfaat bagi pengambilan keputusan saat ini atau saat mendatang

4. Pengertian Akademik

Kata akademik berasal dari bahasa Yunani yakni academos yang berarti sebuah taman umum (plasa) di sebelah barat laut kota Athena. Nama academos adalah nama seorang pahlawan yang terbunuh pada saat perang legendaris Troya. Pada plasa inilah filosof Socrates berpidato dan membuka arena perdebatan tentang berbagai hal. Tempat ini juga menjadi tempat Plato melakukan dialog dan mengajarkan pikiran-pikiran filosofisnya kepada orang-orang yang datang. Sesudah itu, kata acadomos berubah menjadi akademik, yaitu semacam tempat perguruan. Para pengikut perguruan tersebut disebut academist, sedangkan perguruan semacam itu disebut academia. Berdasarkan hal ini, inti dari pengertian akademik adalah keadaan orang-orang bisa menyampaikan dan menerima gagasan, pemikiran, ilmu pengetahuan, dan sekaligus dapat mengujinya secara jujur, terbuka, dan leluasa (Fadjar, 2003:5).

5. Pengertian Sistem Informasi Akademik Menurut Ahmar (2012:10) Sistem Informasi Akademik Sekolah merupakan suatu aplikasi yang membantu sekolah untuk mengelola data-data mengenai data akademik.

\section{Peralatan Pendukung (Tools System)}

1. Unifield Modelling Language (UML) UML merupakan bahasa visual untuk pemodelan dan komunikasi mengenai sebuah sistem dengan menggunakan diagram dan teks-teks pendukung. (Rosa, 2011:117). Pada UML 2.3 terdiri dari 13 macam diagram yang dikelompokkan dalam 13 kategori. Pembagian kategori dan macam-macam diagram tersebut dapat dilihat pada gambar dibawah:

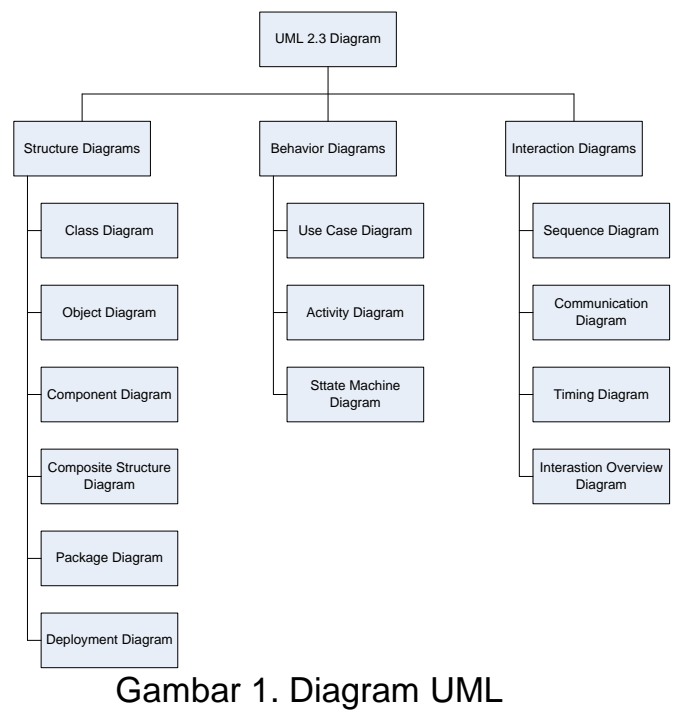

Dari 13 diagram UML yang ada, hanya 4 diagram yang digunakan pada pembuatan sistem ini yaitu activity diagram, use case diagram, sequence diagram, dan deployment diagram. Berikut penjelasan dari masing-masing diagram:

a. Activity Diagram

Diagram aktivitas atau activity diagram menggambarkan workflow (aliran kerja) atau aktivitas dari sebuah sistem atau proses bisnis. Yang perlu diperhatikan disini adalah bahwa diagram aktivitas menggambarkan aktivitas sistem bukan apa yang dilakukan aktor, jadi aktivitas yang dapat dilakukan oleh sistem. (Rosa, 2011:134)

b. Use Case Diagram

Use case atau diagram use case merupakan pemodelan untuk kelakuan (behavior) sistem informasi yang akan dibuat. Use case mendeskripsikan sebuah interaksi antara satu atau lebih aktor dengan sistem informasi yang akan dibuat. Secara kasar, use case digunakan untuk mengetahui fungsi apa saja yang ada di dalam sebuah sistem informasi dan siapa saja yang berhak menggunakan fungsi-fungsi itu. (Rosa, 2011:130)

c. Sequence Diagram

Diagram sekuenmenggambarkan kelakuan objek pada use case dengan mendeskripsikan waktu hidup objek 
dan message yang dikirimkan dan diterima antarobjek. Oleh karena itu untuk menggambar diagram sekuen maka harus diketahui objek-objek yang terlibat dalam sebuah use case beserta metode-metode yang dimiliki kelas yang diinstansiasi menjadi objek itu. (Rosa, 2011:137)

d. Deployment Diagram

Diagram deployment atau deployment diagram menunjukkan konfigurasi komponen dalam proses eksekusi aplikasi. (Rosa, 2011:129)

2. Entity Relationship Diagram (ERD) Entity relationship diagram merupakan sebuah diagram yang digunakan untuk merancang hubungan antartabel-tabel dalam basis data. (Rosa, 2004:212).

Komponen-komponen yang terdapat di dalam Entity Relationship Model:

a. Entitas/Entity

Entitas merupakan data inti yang akan disimpan; bakal tabel pada basis data; biasanya mengacu pada benda yang terlibat dalam aplikasi yang akan dibuat.

b. Atribut

Field atau kolom data yang butuh disimpan dalam suatu entitas

c. Atribut Kunci Primer

Field atau kolom data yang butuh disimpan dalam suatu entitas dan digunakan sebagai kunci akses record yang diinginkan; biasanya berupa id atau kode yang tidak boleh sama atau jika lebih dari satu maka kombinasinya tidak boleh sama; kunci pemanggil benda seperti halnya nama pada manusia.

d. Atribut Multi nilai/Multivalue

Field atau kolom data yang butuh disimpan dalam suatu entitas yang dapat memiliki nilai lebih dari satu.

e. Relasi

Relasi yang menghubungkan antarentitas; biasanya diawali dengan kata kerja; biasanya juga mendefinisikan relasi proses antarentitas/benda yang terkait dengan aplikasi

f. Asosiasi/Association

Penghubung antara relasi dan entitas dimana di kedua ujungnya memiliki multiplicity kemungkinan jumlah
pemakaian

\section{METODE PENELITIAN}

Analisa penelitian yang penulis lakukan dalam pembuatan karya ilmiah ini adalah:

a. Perencanaan (Planning)

Pada tahap ini dilakukan perencanaan terhadap pembuatan aplikasi web dengan menentukan kebutuhan informasi apa saja yang diperlukan, yaitu mulai dari perancangan konsep web, sistem database yang akan digunakan, serta informasi MTsN 37 Jakarta sehingga informasi tersebut dapat membantu dalam pembuatan sistem informasi akademik berbasis web.

b. Analisis

Menganalisa permasalahan yang terjadi untuk dapat menemukan jawaban atas penyebab masalah-masalah yang timbul. Masalah yang ada pada MTsN 37 Jakarta adalah sistem yang ada saat ini kurang efektif dan efisien dikarenakan masih menggunakan microsoft excel.

c. Desain

Sistem informasi akademik berbasis web dibangun dengan menggunakan bahasa pemrograman web PHP serta database MYSQL dan desain sistem dibuat menggunakan UML (Use Case Diagram, Activity Diagram, Sequence Diagram, dan Deployment Diagram). Program ini berisi subsistem mulai dari pengolahan data sekolah yang meliputi pengolahan data siswa, pengolahan data guru, pengolahan data absensi, pengolahan data nilai, serta informasi akademik lainnya.

d. Implementasi

Pada tahapan implementasi ada beberapa hal yang diperhatikan sehingga sistem yang dirancang berfungsi seefisien mungkin, mulai dari persiapan domain, database, penggujian kelayakan, dan juga tidak lepas dari pengujian keamanan sistem serta pelatihan terhadap user sehingga sistem ini dapat diterapkan pada MTsN 37 Jakarta dengan baik.

\section{HASIL DAN ANALISIS}

\subsection{Prosedur Sistem Berjalan}


Prosedur sistem adalah suatu prosedur atau tahap-tahap yang dilakukan sebelum memulai kegiatan untuk menyelesaikan suatu pekerjaan. Prosedur sistem informasi yang berlangsung pada Madrasah Tsanawiyah Negeri 37 Jakarta, yaitu:

1. Prosedur Penerimaan Peserta Didik Baru. Panitia Penerimaan Peserta Didik Baru (PPPDB) melakukan publikasi penerimaan siswa baru. Calon siswa datang untuk mendaftar, PPPDB memberikan formulir pendaftaran kepada calon siswa dan memberitahukan persyaratan yang harus dipenuhi. Calon siswa mengisi formulir kemudian mengembalikan formulir serta berkas kepada PPPDB. PPPDB memberikan kartu tes seleksi masuk kepada calon siswa. Calon siswa melakukan test lisan/wawancara, baca tulis Al-Quran dan test pengetahuan umum sesuai dengan jadwal yang sudah ditentukan PPPDB. PPPDB melakukan penilaian dan mengumumkan hasil test kepada calon siswa dengan memberikan amplop yang berisi hasil seleksi. Calon siswa yang dinyatakan lulus dapat melakukan daftar ulang dan melengkapi berkas. Setelah proses penerimaan peserta didik baru selesai dilaksanakan, PPPDB membuat laporan penerimaan calon siswa, laporan hasil seleksi untuk diserahkan kepada kepala madrasah dan diarsipkan oleh kepala tata usaha.

Berikut adalah activity diagram prosedur penerimaan peserta didik baru:

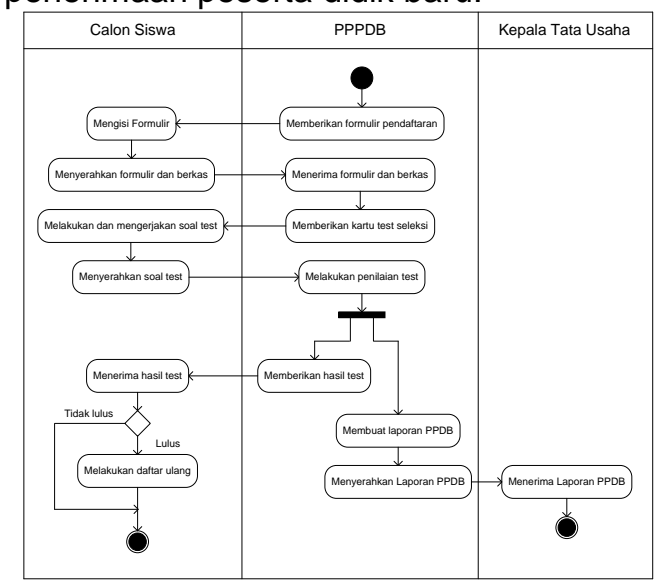

Gambar 2. Activity Diagram Prosedur Penerimaan Peserta Didik Baru

2. Prosedur Pengolahan Jadwal
Bagian kurikulum membuat pembagian tugas mengajar berdasarkan struktur kurikulum pada MTsN 37 Jakarta Berdasarkan pembagian tugas mengajar, bagian kurikulum membuat distribusi jam mengajar guru mata pelajaran per hari dan jadwal pelajaran yang akan diberikan kepada guru dan wali kelas untuk disampaikan kepada siswa. Setelah selesai membuat pembagian tugas mengajar, bagian kurikulum membuat laporan pembagian tugas guru untuk diserahkan kepada kepala madrasah.

Berikut adalah activity diagram prosedur pengolahan jadwal:

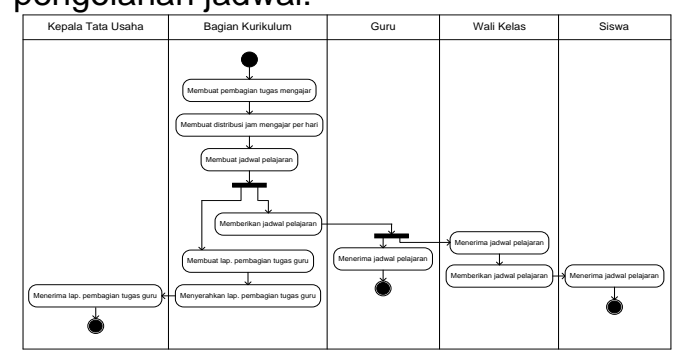

Gambar 3. Activity Diagram Prosedur Pengolahan Jadwal

3. Prosedur Pengolahan Absensi

Ketua kelas/wali kelas melakukan absensi di kelas menggunakan buku absensi, dimana buku absensi tersebut digunakan untuk merekap kehadiran siswa pada buku raport. Setiap walikelas bertugas membuat rekap absensi peserta didik pada setiap semester untuk diserahkan dan diperiksa oleh kepala madrasah.

Berikut adalah activity diagram prosedur pengolahan absensi:

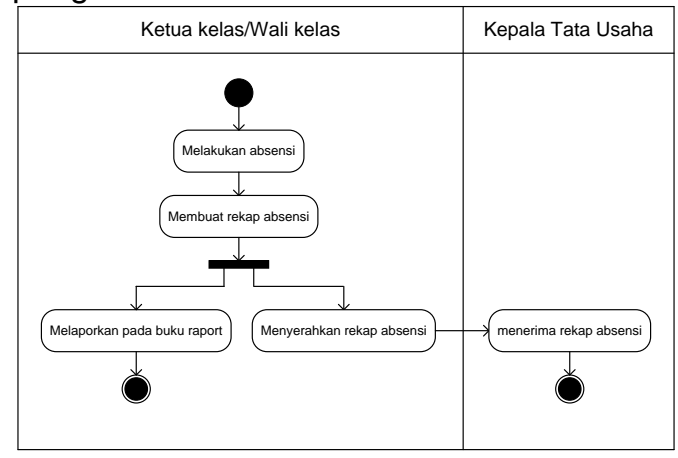

Gambar 4. Activity Diagram Prosedur Pengolahan Absensi

4. Prosedur Pengolahan Nilai 
Nilai siswa diolah oleh setiap guru mata pelajaran berdasarkan nilai tugas, ulangan harian, ujian tengah semester dan ujian akhir semester. Setiap guru mata pelajaran memberikan rekap nilai siswa kepada wali kelas untuk diinput menjadi raport bayangan dan buku raport dengan menggunakan aplikasi microsoft excel kemudian dicetak untuk diberikan kepada wali murid.

Berikut adalah activity diagram prosedur pengolahan nilai:

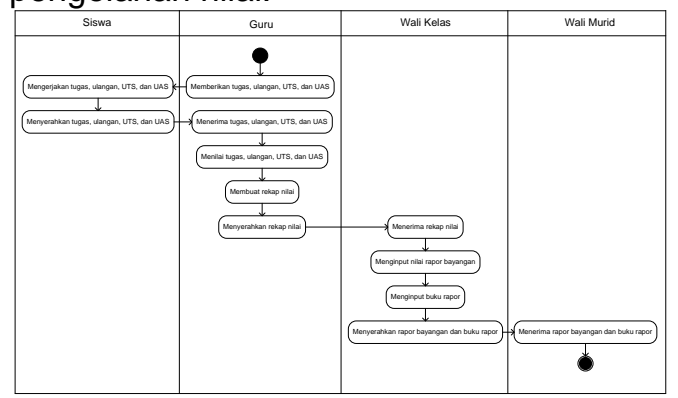

Gambar 5. Activity Diagram Prosedur Pengolahan Nilai

5. Prosedur Penyampaian Laporan

Kepala tata usaha menyerahkan laporan PPDB, laporan pembagian tugas guru, menyerahkan laporan rekap absensi kepada kepala madrasah. Kepala madrasah menerima laporan dan mengecek laporan kemudian menyerahkannya lagi kepada kepala tata usaha dan mengarsipkan laporan-laporan. Berikut adalah activity diagram prosedur penyampaian laporan:

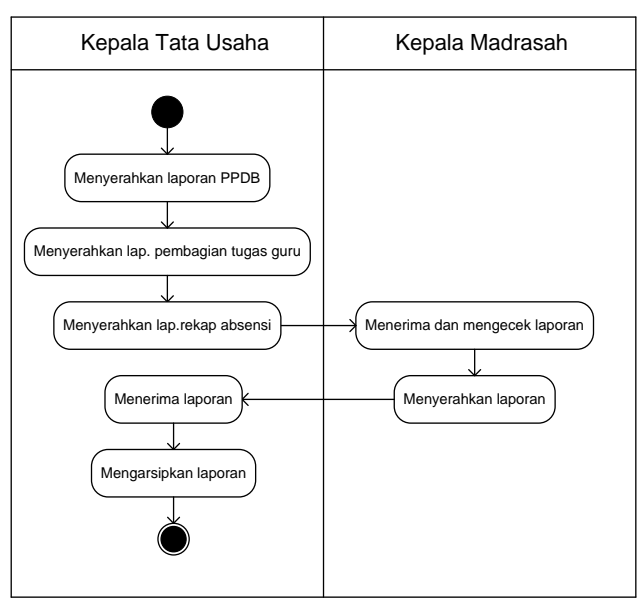

Gambar 6. Activity Diagram Prosedur Penyampaian Nilai
Permasalahan yang sering dihadapi dalam penyampaian informasi akademik di MTs Negeri 37 Jakarta, yaitu:

1. Informasi mengenai MTs Negeri 37 Jakarta masih belum banyak dikenal masyarakat/calon orang tua siswa karena MTsN 37 baru berdiri selama 3 tahun.

2. Sistem informasi akademik mengenai penerimaan siswa baru, pengumuman hasil seleksi siswa baru, informasi absensi, nilai, jadwal dan informasi lainnya yang berhubungan dengan proses Kegiatan Belajar Mengajar (KBM) masih dibuat dengan microsoft excel atau microsoft word sehingga untuk mendapatkan informasi siswa dan orang tua harus datang langsung ke MTs Negeri 37 Jakarta.

Untuk mengatasi masalah yang sudah ada maka dibuatkan aplikasi berbasis web dengan harapan:

1. Masyarakat dapat lebih mengenal keberadaan MTsN 37 Jakarta.

2. Memberikan kemudahan bagi sekolah dalam menginformasikan kegiatan akademik terbaru dimana dan kapan saja kepada calon siswa, siswa, dan guru.

3. Siswa dan guru dapat lebih interaktif untuk mengetahui informasi yang berhubungan dengan kegiatan akademik.

\subsection{Rancangan Sistem dan Program Usulan}

Prosedur sistem usulan yang diusulkan untuk memperbaharui sistem yang sebelumnya pada Madrasah Tsanawiyah Negeri 37 Jakarta, yaitu:

1. Prosedur Penerimaan Siswa Baru (PSB). Proses yang dilakukan calon siswa untuk melakukan pendaftaran yaitu mengisi formulir online melalui menu isi formulir online yang ada pada website MTsN 37 Jakarta, setelah mengisi formulir online, calon siswa diminta untuk mencetak formulir online dan menyerahkannya pada Administrator beserta berkas yang diperlukan. Calon siswa yang sudah menyerahkan formulir online beserta berkas akan diberikan kartu tes seleksi masuk oleh Administrator. Calon siswa melakukan tes seleksi masuk sesuai dengan jadwal yang tertera pada kartu tes seleksi masuk. Administrator melakukan 
penginputan nilai hasil tes seleksi pada database sehingga calon siswa dapat melihat hasil seleksi pada menu lihat hasil seleksi pada website.

2. Prosedur Pengolahan Jadwal

Pengolahan jadwal mengajar guru dan jadwal pelajaran siswa dikelola oleh administrator. Untuk mengelola data jadwal administrator harus melakukan login terlebih dahulu, kemudian administrator dapat memasukkan, mengubah dan menghapus data jadwal. Setelah data jadwal dikelola maka jadwal mengajar guru dan jadwal pelajaran siswa dapat dilihat dan dicetak oleh siswa dan guru di ruang siswa dan ruang guru pada website MTsN 37 Jakarta.

3. Prosedur Pengolahan Absensi

Siswa

Pengolahan absensi siswa dikelola oleh guru yang menjabat sebagai walikelas, proses absensi dilakukan setiap hari secara online. Untuk melakukan absensi, walikelas harus melakukan login terlebih dahulu, kemudian walikelas dapat memasukkan, mengubah dan menghapus data absensi siswa. Data kehadiran siswa dapat dilihat oleh siswa pada raport tengah semester dan raport akhir semester dengan mengakses ruang siswa pada website MTsN 37 Jakarta.

4. Prosedur Pengolahan Nilai

Proses penilaian dikelola oleh masingmasing guru mata pelajaran berdasarkan kehadiran siswa, tugas, ulangan harian, UTS dan UAS. Untuk melakukan pengolahan nilai, guru harus melakukan login terlebih dahulu, kemudian guru dapat memasukkan, mengubah dan menghapus data nilai siswa. Data nilai yang dikelola oleh guru akan ditampilkan menjadi raport tengah semester dan raport akhir semester yang dapat dilihat oleh siswa dengan mengakses ruang siswa pada website MTsN 37 Jakarta.

\section{Use Case Diagram}

Use case diagram dalam perancangan sistem informasi Madrasah Tsanawiyah Negeri 37 Jakarta sebagai berikut:

1. Use Case Penerimaan Siswa Baru

Use case penerimaan siswa baru dapat dilihat dibawah ini, yaitu:

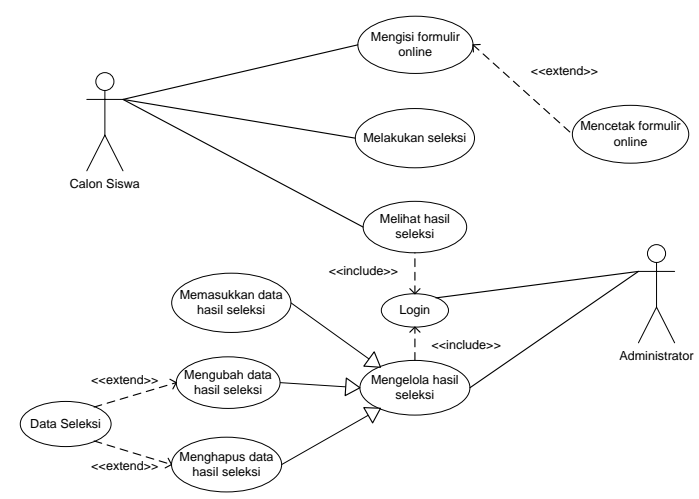

Gambar 7. Use Case Penerimaan Siswa Baru

2. Use Case Pengolahan Jadwal Use case pengolahan jadwal dapat dilihat pada gambar di bawah ini:

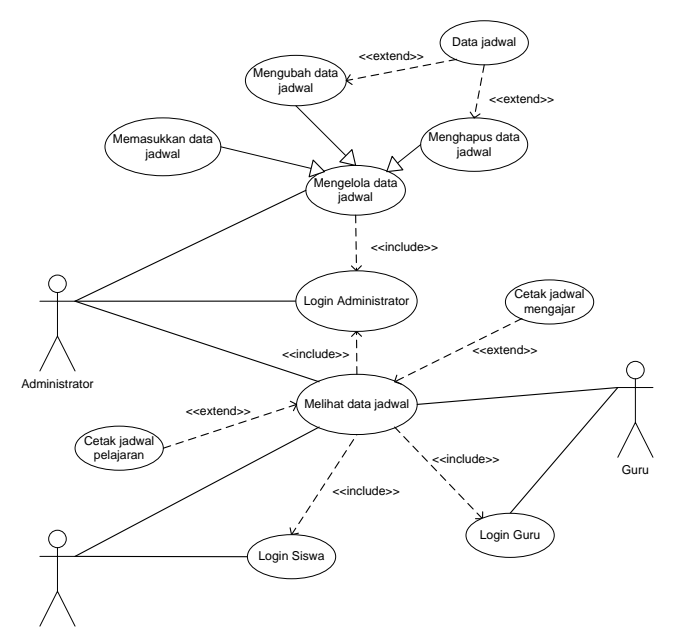

Gambar 8. Use Case Pengolahan Jadwal

3. Use Case Absensi Siswa

Use case absensi siswa dapat dilihat pada gambar di bawah ini:

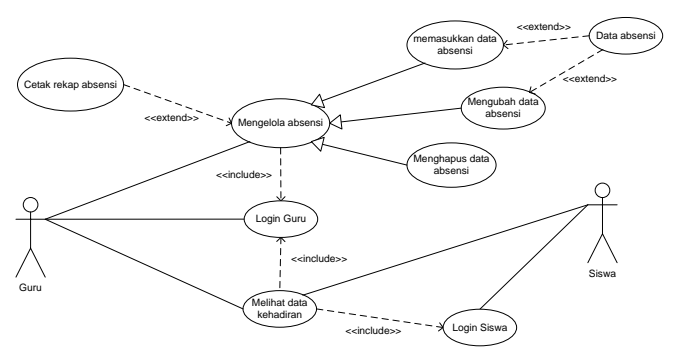

Gambar 9. Use Case Absensi Siswa 
4. Use Case Pengolahan Nilai Use case pengolahan nilai dapat dilihat pada gambar di bawah ini:

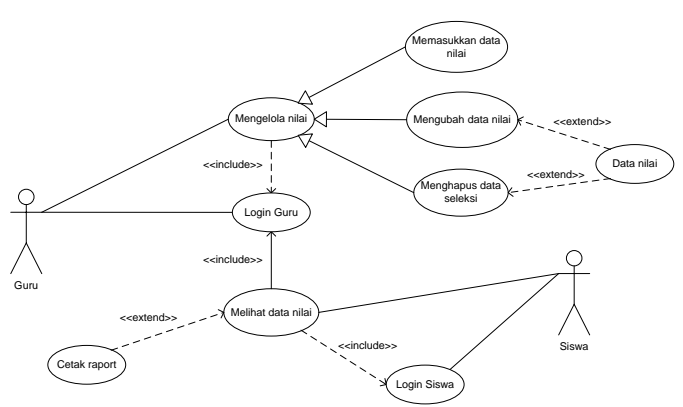

Gambar 10. Use Case Pengolahan Nilai

\subsection{Desain Database}

Entity Relationship Diagram menjelaskan hubungan antar data dalam basis data yang terdiri dari object-object dasar yang mempunyai hubungan atau relasi antar objek-objek tersebut. Dibawah ini $E R D$ yang dibuat dalam sistem: 


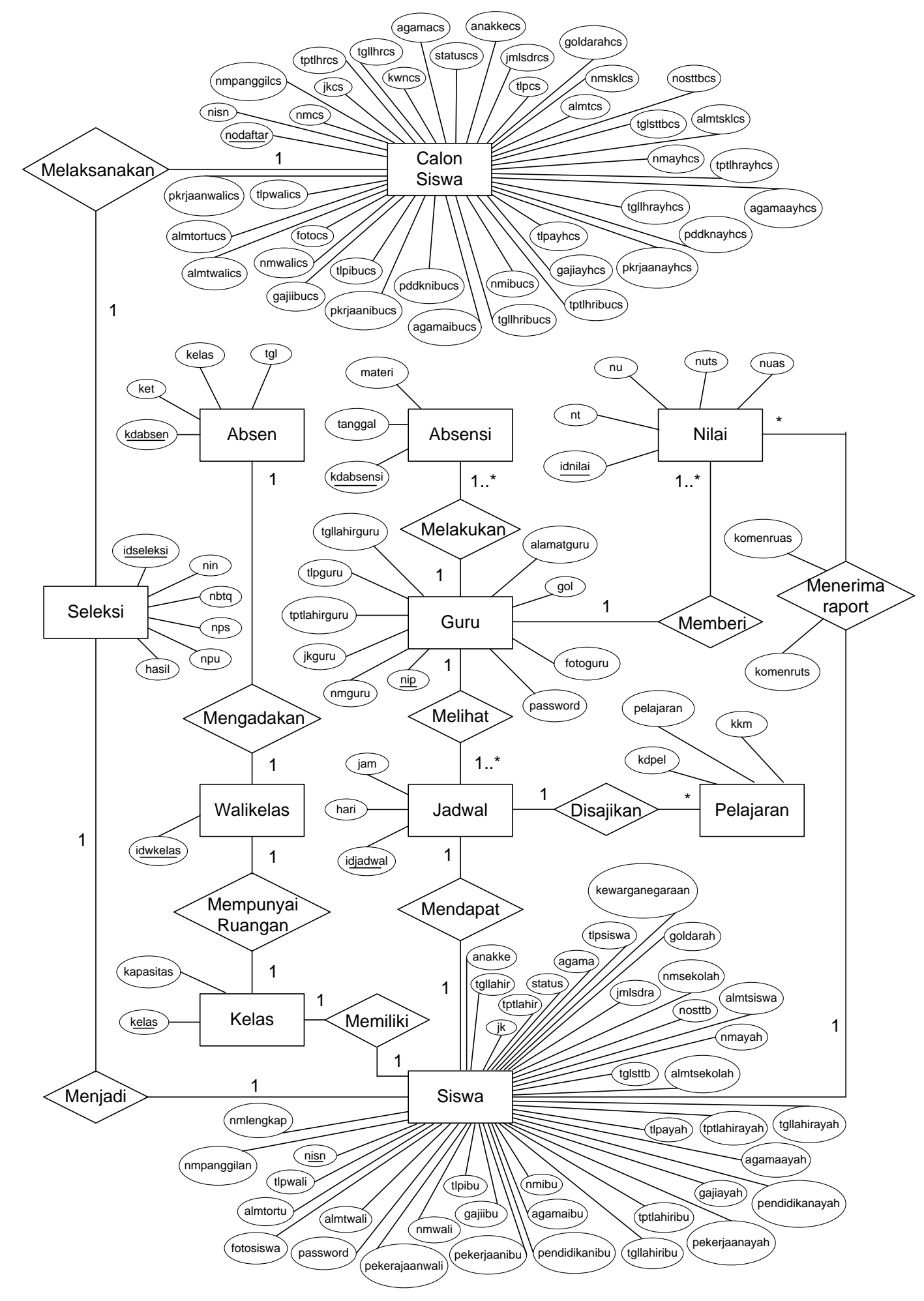

Gambar 11. Entity Relationship Diagram (ERD) 


\subsection{Tampilan Web}

1. Halaman Awal (index)

Halaman index adalah tampilan yang muncul awal dari website yang pertama kali dilihat oleh pengunjung web. Tampilan dari halaman index adalah:

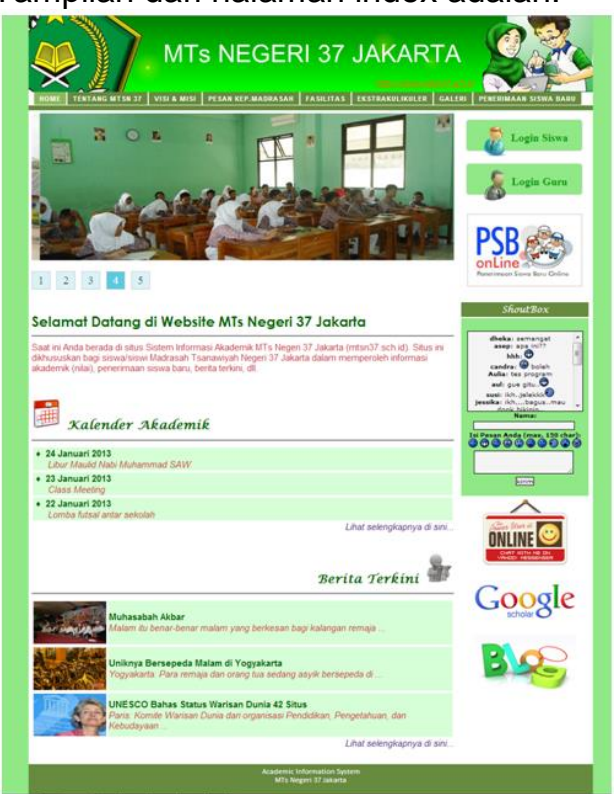

Gambar 12. Tampilan Halaman Index

3. Halaman Penerimaan Siswa Baru

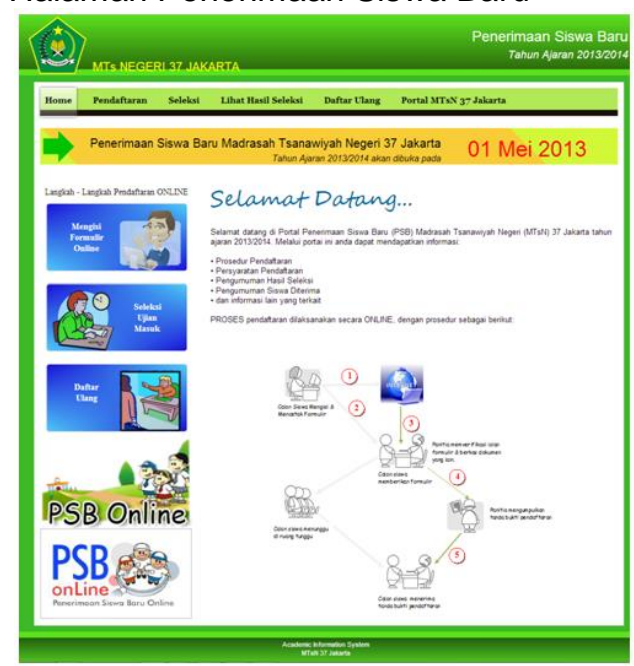

Gambar 13. Tampilan Halaman Penerimaan Siswa Baru

\section{Halaman Home Ruang Siswa}

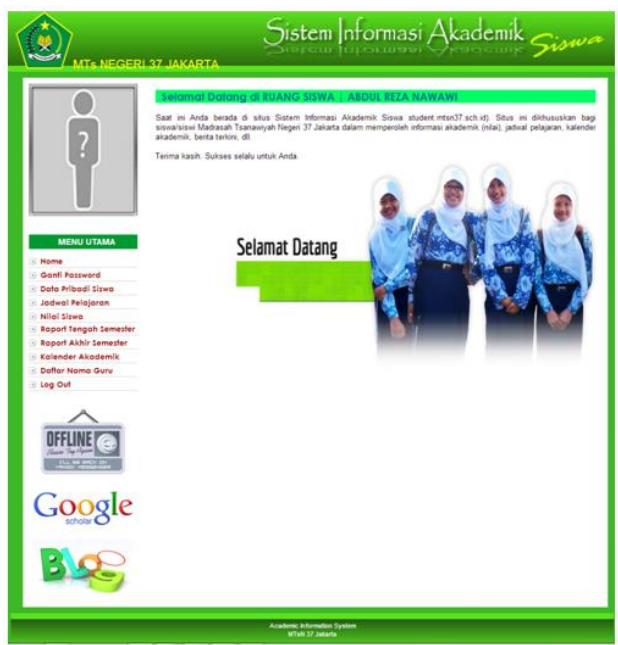

Gambar 14. Tampilan Halaman Home Ruang Siswa

4. Halaman Home Ruang Guru 

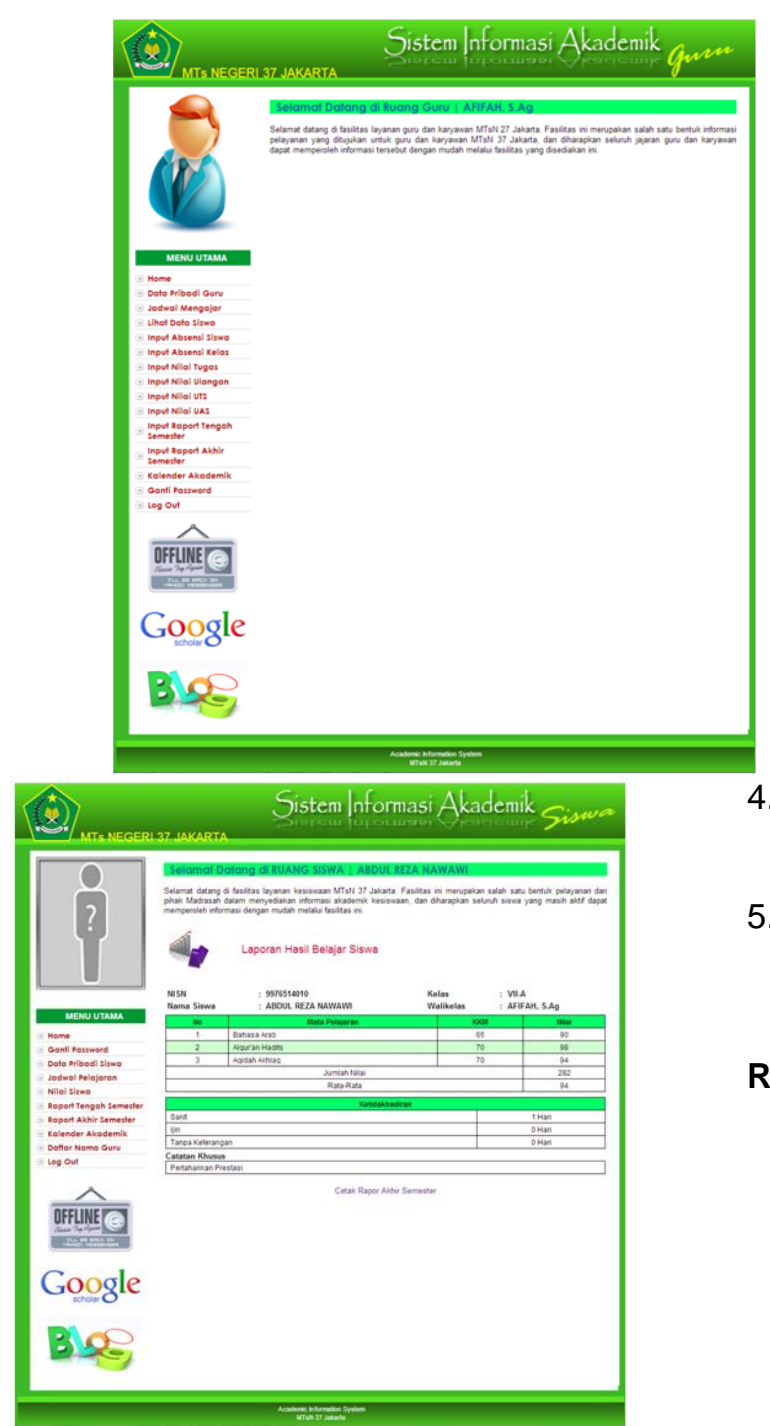

Gambar 16. Tampilan Halaman Raport Akhir Semester

\section{Penutup}

Dari pembuatan website dan hasil riset di Madrasah Tsanawiyah Negeri 37 Jakarta, maka penulis memberikan kesimpulan, yaitu:

1. Dalam pembuatan aplikasi berbasis web, PHP dapat dijadikan sebagai salah satu pilihan utama karena keunggulannya dan kemudahan dalam pemakaian.

2. MySQL sebagai server database untuk aplikasi PHP, Kemudahannya dalam integrasi ke berbagai aplikasi web.

3. Dengan penerapan dan pemanfaatan sistem informasi akademik ini bisa menjadi solusi alternatif pelaksanaan pekerjaan sesuai tugas pokok dan fungsi bagi pengguna sistem.

\author{
Gambar 15. Tampilan Halaman Home \\ Ruang Guru
}

5. Halaman Raport Akhir Semester

4. Pelayanan terhadap pengguna sistem, khususnya siswa menjadi lebih baik dan cepat.

5. Pelayanan terhadap pengguna sistem, khususnya mahasiswa menjadi lebih baik dan cepat.

\section{REFERENSI}

[1]. Ahmar, Ansari Saleh. 2012. Panduan Sistem Informasi Akademik Sekolah Berbasis Web. Yogyakarta: Lokomedia.

[2]. Davis, Gordon B. 2003. Sistem Informasi Manajemen I. Jakarta: PT. Pustaka Binawan Pressindo.

[3]. Fadjar, 2003. Mahasiswa dan Budaya Akademik. Bandung: Rineka.

[4]. Jogiyanto, H.M. 2005. Analisis dan Desain Sistem Informasi, Edisi Kedua. Yogyakarta: ANDI.

[5]. Sukamto, Rosa Ariani dan M. Shalahuddin. 2010. Modul Pembelajaran Pemrograman Berorientasi Objek. Bandung: Modula

[6]. Susanto, Azhar. 2004. Sistem Informasi Manajemen Konsep dan Pengembangannya. Bandung: Lingga Jaya

[7]. Andi, Kristanto. 2003. Perancangan Sistem Informasi dan Aplikasinya. Yogyakarta: Gava Media

[8]. Anhar. 2010. Panduan Menguasai PHP dan MySQL secara otodidak. Jakarta: Media Kita

[9]. Binanto, Iwan. 2005. Konsep Bahasa Pemrograman. Yogyakarta: Andi.

[10]. Darma, Jarot S dan Shenia A. 2009. Buku Pintar Internet. Jakarta : MediaKita.

[11].Dengen, Nataniel dan Dyna Marissa Kh. 2009. Sistem Informasi Akademik Berbasis Web SMP Negeri 4 Samarinda. Vol 4. No 2, 
Juli $2009 . \quad$ Diambil dari:http://id.pdfsb.com/readonline/59466c47 64513937566 e56304448746a56413d3d3848307 (25 Januari 2013)

[12]. Indrayani, Etin. 2011. Pengelolahan Sistem Informasi Akademik Perguruan Tinggi Berbasis Teknologi Informasi dan Komunikasi (TIK). Vol 12. No.1 April 2011. Diambil dari: http://jurnal.upi.edu/penelitianpendidikan/view/437/pengelolaan-sisteminformasi-akademik--perguruan-tinggiberbasis-teknologi--informasi--dankomunikasi-(tik).html (25 Januari 2013)

[13].Kristanto, Andri. 2010. Kupas Tuntas PHP dan MySQL. Klaten: Cable Book.

[14].Ladjamudin, Al-Bahra Bin. 2005. Analisis dan Desain Sistem Informasi. Yogyakarta: Graha IImu

[15].Madcoms. $2009 . \quad$ Menguasai XHTML,CSS,PHP dan MySQL melalui Dreamweaver. Yogyakarta: Andi.
[16]. Prakoso, Bimo Seto dan Meliana Christianti. 2008. Analisis dan Perancangan Sistem Informasi Akademik dengan Studi Kasus pada Sekolah Menengah Atas Terpadu (SMAT) Krida Nusantara. Vol. 3 No. 1 Maret 2008 : 75 - 90. Diambil dari: http://repository.maranatha.edu/id/eprint/422 (25 Januari 2013)

[17]. Ramadhan, Arief. 2005. SQL Server 2000 dan Visual Basic 6. Jakarta: PT. Elex Media Komputindo.

[18].Sanjaya, Ridwan. 2009. Cara Kilat Mempunyai Website Sendiri - Lanjutan. Jakarta: PT. Elex Media Komputindo.

[19].Sukamto, Rosa Ariani dan M. Shalahuddin. 2011. Modul Pembelajaran Rekayasa Perangkat Lunak Terstruktur dan Berorientasi Objek. Bandung: Modula

[20].Sutabri, Tata. 2004. Sistem Informasi Akuntansi. Yogyakarta: ANDI 